\title{
OBSERVATIONS ON SINGLE BRUCELLLOSIS REACTORS IN LARGE HERDS
}

\author{
K. F. Trueman, Annette D. Thomas and G. A. Spinks \\ Queensland Department of Primary Industries, \\ Oonoonba Veterinary Laboratory, Townsville, \\ Queensland, 4810
}

\begin{abstract}
SUMMARY: Over a 3 year period specimens were collected from single reacting cattle to the complement fixation test for brucellosis from large herds in north Queensland. Twenty-four such reactors were destroyed for culture, and Brucella aborfus was isolated on 3 occasions. The existence of such low levels of $\mathrm{Br}$. abortus in large herds should not be overlooked in the eradication campaign.

Explanations were found for 17 of the single reactors, and included introduction of cattle to the herd, exposure to adjoining infected herds or vaccination with Strain 19.
\end{abstract}

\section{Introduction}

Serological testing in North Queensland associated with the National Brucellosis Eradication Campaign, has revealed a number of herds containing a single reactor to the complement fixation test (CFT). The significance of these reactors is unknown, but their occurrence can be a cause of concern when classifying herds as infected or noninfected.

\section{Materials and Methods}

From January 1975 until December 1977 single CFT reactors were slaughtered and specimens taken for culture. Samples were reccived from 24 animals representing 23 properties. Other single reacting animals were localed, but no specimen were received from these for culturc. Only herds of at least 300 breeding animals, and in which the prevalence of $\mathrm{CFT}$ reactor was $0.33^{6 / \%}$ or less, were considered. All serums from herd blecdings were subjected to the Rose Bengal test (RBT) (Morgan et al 1969), and any serums agglutinating with RBT antigen were then tested in the CFT. Until February 1976 the CFT was performed employing warm fixation in ubes. Serial dilutions from $1 / 5$ to $1 / 80$ were set up. Subsequently the nicro CFT was employed with dilutions from $1 / 4$ to $1 / 256$. The Australian Standard Method (Anon. 1977) was followed. After slaughter at least 3 and up to 9 tissues were submitted on ice from each single reacling animal. Supramammary lymph nodes werc always received from female cattle, and other specimens included relropharvigeal, ischiatic and iliac lymph nodes, spleen, uterus, udder, milk, foctus and any suspect lesion. From bulls the specimens included testes, scminal vesicles, iliac and superficial inguinal lymph nodes and spleen.

Tissues were alcohol flamed (Alton et al 1975) and then homogenised separately in serum broth. A.t all times individual samples were plated onto sheep blood agar and MacConkey agar, and incubated aerobically at $37^{\circ} \mathrm{C}$ for 3 to 5 days. Samples were also plated onto sheep blood agar which was incubated at $37^{\circ} \mathrm{C}$ in an almosphere containing $10^{\%} \% \mathrm{CO}_{2}$. From December 1975 until December 1976 a selective Brucella agar with antibiotics (Nelson et al 1966) was included and was in cubaled in the same say. From lanuary 1977 Brucella agars A and $C$ and Brucella broth (Brodie and Sinton 1975) were inoculated and incubated at $37^{\circ} \mathrm{C}$ in an atmosphere containing
$10 \% \mathrm{CO}_{2}$. For the biological test, homogcnised lymph nodes were pooled, and other homogenised lissues were placed in a second pool. Fron each pool $1 \mathrm{ml}$ was inoculated intraperitoneally into a separate guinea pig. After 6 weeks the guinea pigs were sacrificed, and serums collected for the RBT and CFT. A portion of the splcen was removed, and rubbed over a blood agar and a Brucella selective plate of the period and incubated. Colonies resembling Br. aborlus by agglutination and staining techniques from either primary ar biological methods were sent to the WHO Brucellosis centre at the Commonwealth Serum Laboratories, Parkville, Victoria, for biotyping.

Enquiries were conducted on each property in an attempt to explain the reason for the single reacting animals.

\section{Results}

From the 24 single reacting animals $B r$. abortus was isolated on 3 occasions (Table 1), all isolates being recovered only following guinea pig inoculation.

Pooled organs including foetal tissues yielded $\mathrm{Br}$. abortus biotype 1 from the cow detected on property No. 1. No cattle had been introduced into the herd for the previous 15 years, apart from the possible exception of bulls. Cattle on surrounding properties were tested and no RBT reactors were found. Br. abortus biotype 1 was recovered from the supramammary lymph node of a cow from property No. 2. Animals from an adjoining infected property were known to get onto this property. The cow from property No. 3 had a swollen bursa under the ligamentum nuchae, and from the contents of the bursa pooled with udder tissue $\mathrm{Br}$. abortus biotype 2 was isolated. No cattle had been introduced onto this property for several years. One adjoining property was found to be infected.

Of the remaining 21 single reactor animals $8 \mathrm{had}$ been introduced to the herds ( 3 from properties subsequently found to be infected), 4 were on 
TABLE 1

Single Complement Fixation Reactors from which Brucella abortus was Isolated

\begin{tabular}{|c|c|c|c|c|c|c|c|}
\hline $\begin{array}{l}\text { Animal } \\
\text { and } \\
\text { Property } \\
\text { Number }\end{array}$ & $\begin{array}{l}\text { No. of } \\
\text { Breeders }\end{array}$ & $\begin{array}{c}\text { No. of } \\
\text { RBT } \\
1975-77\end{array}$ & $\begin{array}{l}\text { No. } \\
\text { RBT+ }\end{array}$ & $\begin{array}{r}\text { Age } \\
\mathrm{Re}\end{array}$ & $\begin{array}{l}\mathrm{CF} \\
\text { Titre }\end{array}$ & $\begin{array}{c}\text { Gestation } \\
\text { Status }\end{array}$ & $\begin{array}{c}\text { Status } \\
\text { of } \\
\text { Adjoining } \\
\text { Properties }\end{array}$ \\
\hline 1 & 1,800 & 1,505 & 1 & $4 y$ & $80+$ & $8 \mathrm{~m}$ & tested negative \\
\hline 2 & 2,000 & 4,293 & 2 & $6 y$ & $80+$ & Empty & 1 infected \\
\hline 3 & 2,000 & 3,974 & 2 & $6 y$ & $64^{*}$ & Pregnant ${ }^{+}$ & 1 infected \\
\hline
\end{tabular}

properties adjoining infected herds and 2 had been vaccinated with Strain 19. No explanation could be found for the other 7 single reactor animals.

\section{Discussion}

Nelson et al (1966) reported a recovery rate of $80 \%$ from the supramammary lymph nodes of cattle infected with $\mathrm{Br}$. abortus, and with the inclusion of other nodes and tissues up to $93 \%$ could be expected. It is possible therefore that more of the single reactor cattle may have been infected, but were not detected by culture.

The use of selective media as described by Brodie and Sinton (1975) is reported to be equally as sensitive as guinea pig inoculation when examining tissues for $\mathrm{Br}$. abortus (Robertson et at 1977). Our 3 isolates were made prior to using the media of Brodie and Sinton (1975), and this could explain the failure to detect $B r$. abortus on primary culture, although contaminating organisms were only a problen in a few instances.

Examination of the herd history often provided an explanation for the apparent exposure to $B r$. abortus. However, satisfactory explanations could not be found for some of the single reactors, including 1 of the 3 animals from which Br. abortus was isolated. It is possible that in some cases the serological titres may have been due to other factors such as cross reaction with Yersinia enterocolitica (Ahvonen et al 1969), Also as feral pigs are numerous on most of the propertics concerned, exposure to $B r$. suis (Norton and Thomas 1976) may have been involved.

Prior to the eradication campaign, Rogers et al (1972) using the serum agglutination test, found the serological incidence of brucellosis in north Queensland was only $1.8 \%$, and if 4 Barkly Tableland properties were excluded the overall incidence of reactors was reduced to $0.4 \%$. Despite the generally low incidence, it would seem unusual for $B r$. abortus infection to exist in single breeding animals without spread to susceptible, in-contact females. However, our 3 isolations of $\mathrm{Br}$. abortus from 24 single serological reactors indicate that a very low level of infection can exist under the circumstances described. This being so, it is important to the eradication campaign that single reactors not be lightly dismissed or casually explained.

\section{Acknowledgments}

The considerable assistance given by staff of the Veterinary Services Branch in collecting specimens and obtaining herd histories is gratefully acknowledged. We are also grateful to the Commonwealth Serum Laboratories for typing the strains of Bri, aborius.

\section{References}

Ahvonen, P., Jansson, Elli and Aho, K. (1969) - Acta, path. microbiol. scandinav. 75: 291.

Alton, G. G. , Maw, J., Rogerson, B. A. and McPherson, G. G. (1975)-Aust. vet. J. 51: 57.

Anon. (1977) - Alsst. vet. J.53: 394

Brodie, I. and Sinton, G. P. (1975) - I. Hyg., Camb. 74: 359.

Morgan, W. J., Brinley, Mackimon, D. I., Lawson, .I. R. and Cullen, G. A. (1969) - Vet. Rec. 85: 636.

Nelson, C. J., Anderson, R. K.. Kimberling, C. V. and Pietz, D. E. (1966) - Am. J. vet. Res. 27: 1515.

Norton, J. H. and Thomats, Annette D. (1976) - Aust. vet. I. 52: 293 .

Robertson, L., Farrell, I. D. and Hinchliffe, P. M. (1977) Br. vet. J. 133: 193.

Rogers, R. J., Flanagan, M. and Hill, M. W. M. (1972) Aust. vet. I. 48: 203 .

\section{Addendum}

Since subnission of this article a further 1200 tests have been performed on property No. 1 and another C.FT reactor detected (litre 4/128). This was a 6 year old homebred empty cow, and $\mathrm{Br}$. abortus was isolated from the supramammary lymph nodes on primary culture. It is unknown if this cow had been previousty bled for testing. 